\title{
Date of Additional Surgery for New Tumor
}

\section{Event}

National Cancer Institute

\section{Source}

National Cancer Institute. Date of Additional Surgery for New Tumor Event. NCI

Thesaurus. Code C156859.

The date of additional surgery for the new tumor event. 